\title{
Sistem Pakar Diagnosa Virus Corona Dengan Metode Naïve Bayes
}

\author{
Fareza Aditiyanto Nugroho'); Arif Fajar Solikin'2); Mutiara Dwi Anggrainii ${ }^{3)}$; Kusrini ${ }^{4}$ \\ 1,2,3,4) Magister Teknik Informatika, Universitas Amikom Yogyakarta \\ 1)fareza.1268@students.amikom.ac.id; ${ }^{2)}$ arif.1311@students.amikom.ac.id; \\ ${ }^{3)}$ mutiara.1307@students.amikom.ac.id; ${ }^{4}$ kusrini@amikom.ac.id
}

\begin{abstract}
Humans being are faced with non-natural disasters which have bad effect for population on the world. This non-natural disaster is called Corona Virus Disease (COVID-19). This COVID-19 will become a pandemic in 2020. This types of COVID-19 is coming from the Orthocronavirinae. It belongs to the Coronaviridae and the Nidovirales. This type of that virus has caused some disease to birds, mammals and also human being. Therefore, the research was conducted. The result of this research will give the information about system which related the classification human being according to their transmission to the body. This research used naïve bayes method. The result of this research is diagnostic system with the level of accuracy $94 \%$. Thus, COVID-19 diagnostic expert system used to know the level of COVID -19 infections to human being. It can help the user knowing the next treatment.
\end{abstract}

Keywords : Expert System, Naïve Bayes, Coronavirus, Covid-19

\section{PENDAHULUAN}

Saat ini, dunia tengah mewaspadai penyebaran virus bernama virus corona. Virus Corona (CoV) merupakan bagian dari rangkaian virus penyebab berbagai penyakit, mulai dari influenza hingga penyakit yang lebih serius seperti Middle East Respiratory Syndrome (MERS-CoV) dan Severe Acute Respiratory Syndrome (SARS-CoV). Penyakit yang disebabkan oleh virus korona (juga dikenal sebagai COVID-19) ini merupakan jenis baru yang ditemukan pada tahun 2019 dan belum pernah ditemukan menyerang manusia sebelumnya. Kasus virus corona pertama kali muncul di Provinsi Wuhan, China dan menyerang manusia. Serangan dini dianggap pneumonia, dan gejalanya biasanya mirip dengan flu. Gejala tersebut antara lain batuk, demam, kelelahan, sesak napas dan kehilangan nafsu makan. Namun, tidak seperti influenza, virus corona dapat berkembang pesat, menyebabkan infeksi yang lebih serius dan kegagalan organ. Keadaan darurat ini terutama terjadi pada pasien dengan gangguan kesehatan sebelumnya. Akibat cepatnya penyebaran virus corona, Badan Kesehatan Dunia (WHO) menyatakan virus corona sebagai pandemi pada 11 Maret 2020. Pandemi atau pandemi global mengindikasikan bahwa penyebaran COVID-19 sedang terjadi, sehingga hampir tidak ada negara di dunia yang dapat memastikan terlindung dari virus corona [1].

Perkembangan kondisi pandemi COVID19 akhir-akhir ini semakin mengkhawatirkan dengan ditandainya pertambahan jumlah kasus terkonfirmasi positif dari hari ke hari khususnya di Indonesia dan umumnya di seluruh dunia. Kasus COVID-19 pertama di Indonesia diumumkan empat bulan setelah kasus pertama China diumumkan. Kasus pertama di Indonesia pada Maret 2020 sebanyak 2 kasus, dan 2 kasus ditemukan kembali pada 6 Maret. Jumlah kasus COVID19 terus bertambah. Untuk menentukan apakah seseorang terjangkit COVID-19, diperlukan pemeriksaan PCR. Hasil penelitian terbaru menunjukkan bahwa beberapa kasus dapat menunjukkan hasil positif yang terusmenerus meskipun tidak ada gejala. Penelitian di Korea Selatan menunjukkan bahwa meskipun tidak ditemukan virus yang mereplikasi 3 minggu setelah gejala pertama muncul, SARS-CoV-2 RNA masih dapat dideteksi dalam sampel RT-PCR selama 12 minggu. Bagi penyintas COVID-19, penelitian terbaru juga menunjukkan kemungkinan proses infeksi ulang, karena antibodi COVID19 di dalam tubuh diperkirakan akan hilang dalam waktu 3 hingga 12 bulan. Oleh karena itu, meskipun sudah dinyatakan sembuh dari COVID-19, tetap harus menerapkan prosedur kesehatan.

Pertambahan jumlah kasus terkonfirmasi sebagian besar disebabkan oleh penularan virus antar keluarga dan orang terdekat dalam satu komunitas, dimana seseorang dengan gejala ringan COVID-19 masih belum menyadari jika dirinya sudah mulai terinfeksi virus. Beberapa kasus yang terjadi, seorang kakek di Jakarta mengalami demam, dimana keluarganya menganggap demam yang 
terjadi adalah akibat penyakit typhus. Namun Ketika test PCR dilakukan dan hasilnya positif, maka terjadi kekhawatiran di tengah keluarga yang pada akhirnya mereka semua melakukan test PCR dan diketahui 7 dari 10 anggota keluarga terkonfirmasi positif. Kasus lain di Jawa Tengah seorang pegawai merawat orang tuanya di rumah dan rawat jalan di rumah sakit, beberapa hari kemudian pegawai tersebut mengalami demam ringan, masuk angin dan kehilangan indera penciumannya untuk sesaat. Ketika kantornya mengadakan rapid test dan hasilnya menunjukkan reaktif, kemudian dilanjutkan PCR dan hasilnya positif, akhirnya satu keluarga terkonfirmasi positif semua. Banyaknya jumlah kasus terkonfirmasi positif menyebabkan okupansi rumah sakit untuk isolasi pasien dan penanganan pasien kategori sedang dan berat mengalami lonjakan. Sementara jumlah tenaga keseahatan jumlahnya terbatas.

Berdasarkan keterangan resmi Menteri Kesehatan Republik Indonesia, jumlah tenaga kesehatan seluruhnya berjumlah 1,7 juta nakes berbanding 268 juta penduduk Indonesia dengan angka kematian nakes yang mencapai 504 jiwa. Kondisi ini telah menyentak perasaan dan pikiran kita untuk memberikan kontribusi dalam penanganan pandemic COVID-19 pada tahap edukasi dan pemahaman masyarakat tentang COVID-19. Berangkat dari hal tersebut diatas dilakukanlah penelitian tentang penerapan algoritma naïve bayes pada system pakar prediksi COVID-19 untuk memprediksi apakah seseorang terinfeksi virus CORONA berdasarkan symtoms atau gejala-gejala fisik yang dialaminya untuk kemudian diberikan solusi atau rekomendasi tindakan. Sistem pakar ini melibatkan dua dokter spesialis paru dan spesialis THT-KL, dengan sistem pengambilan keputusan menggunakan algoritma naïve bayes.

\section{TINJAUAN PUSTAKA}

Sistem Pakar adalah salah satu aplikasi kecerdasan buatan yang paling umum. Ini adalah program komputer yang mensimulasikan keputusan dan tindakan seseorang atau asosiasi yang memiliki fakta dan pengalaman khusus dalam bidang tertentu. Biasanya, sistem semacam itu berisi basis pengetahuan yang berisi pengalaman terakumulasi dan seperangkat aturan untuk menerapkan basis pengetahuan ke situasi tertentu. Fungsi utama sistem pakar adalah antarmuka pengguna, representasi data, kesimpulan, penjelasan, dll. Keuntungan dari sistem pakar adalah untuk meningkatkan keandalan, mengurangi kesalahan, mengurangi biaya, menggunakan berbagai keterampilan, menyediakan basis data intelijen, dan mengurangi bahaya. Kerugian dari sistem pakar adalah tidak adanya akal sehat dan tidak ada perubahan lingkungan [2].

Sistem pakar telah banyak digunakan di berbagai bidang. Salah satunya digunakan dalam bidang kedokteran, khususnya untuk diagnosa penyakit. Sabreen dan Naser menggunakan Sistem Pakar untuk mendiagnosa penyakit pergelangan kaki. Tujuh penyakit pergelangan kaki telah diidentifikasi dengan Sistem Pakar: Pergelangan Kaki Terkilir, Fraktur (Fibula), Rheumatoid Arthritis, Rheumatoid Fever, Gout, dan Osteoarthritis (Degenerative Joint) menggunakan SL5 Object Expert System Language dalam pekerjaan sistem pakar [3].

Dalam hal ini, sistem pakar akan digunakan untuk mendiagnosis SARS, MERS, dan COVID-19. Ketiga penyakit tersebut merupakan penyakit infeksi virus pernapasan dan dapat berakibat fatal [4]. Sindrom Pernafasan Akut Parah atau SARS adalah infeksi saluran pernafasan yang disebabkan oleh SARS-related coronavirus (SARS-CoV). Gejala awalnya mirip dengan flu, tetapi akan cepat memburuk. SARS pertama kali ditemukan di Guangdong, Cina pada tahun 2002, dan tidak ditemukan sampai awal tahun 2003 [5][6].

Sindrom Pernafasan Timur Tengah (MERS) adalah subtipe baru dari virus korona yang belum pernah ditemukan menginfeksi manusia sebelumnya. Kebanyakan penderita MERS akan mengalami gangguan pernapasan akut yang parah, disertai demam, batuk, dan sesak napas. Sekitar 3-4 kematian dari 10 pasien yang melaporkan MERS (CFR 30-40\%). Virus ini diketahui pertama kali menyerang manusia di Yordania pada April 2012, namun kasus pertama yang dilaporkan adalah kasus di Arab Saudi pada September 2012 [7][8].

Algoritma Naive Bayes merupakan salah satu algoritma dalam teknologi klasifikasi yang mudah diimplementasikan dan cepat dalam kecepatan pemrosesan [9]. Algoritma Naïve Bayes didasarkan pada probabilitas bersyarat. Ini menggunakan Teorema Bayes, rumus itu menghitung probabilitas dengan menghitung frekuensi nilai dan kombinasi nilai 
dalam sejarah data. Teorema Bayes menemukan probabilitas suatu peristiwa terjadi mengingat probabilitas peristiwa lain yang telah terjadi [10]. Metode Naïve Bayes menggunakan model statistik untuk melakukan proses klasifikasi data. Metode ini menghitung nilai probabilitas data uji berdasarkan data kasus yang sudah pernah terjadi [11].

Berikut ini perhitungan pada probabilitas naïve bayes:

$$
P(A \mid B)=\frac{P(B \mid A) P(B)}{P(A)} \ldots \ldots
$$

Keterangan:

$\begin{array}{ll}\mathrm{P}(\mathrm{A} \mid \mathrm{B}) & \begin{array}{l}\text { : Peluang A jika diketahui } \\ \text { keadaan jenis gejala B }\end{array} \\ \mathrm{P}(\mathrm{B} \mid \mathrm{A}) & \begin{array}{l}\text { : Peluang evidence B jika } \\ \text { diketahui hipotesis } \mathrm{A}\end{array} \\ \mathrm{P}(\mathrm{B}) & \begin{array}{l}\text { : Probabilitas } \mathrm{B} \text { tanpa melihat } \\ \text { evidence apapun }\end{array} \\ \mathrm{P}(\mathrm{A}) & \text { : Peluang evidence gejala } \mathrm{A}\end{array}$

\section{METODE PENELITIAN}

Metode penelitian merupakan prosedur dan teknik penelitian. Alur penelitian ditunjukkan pada Gambar 1.

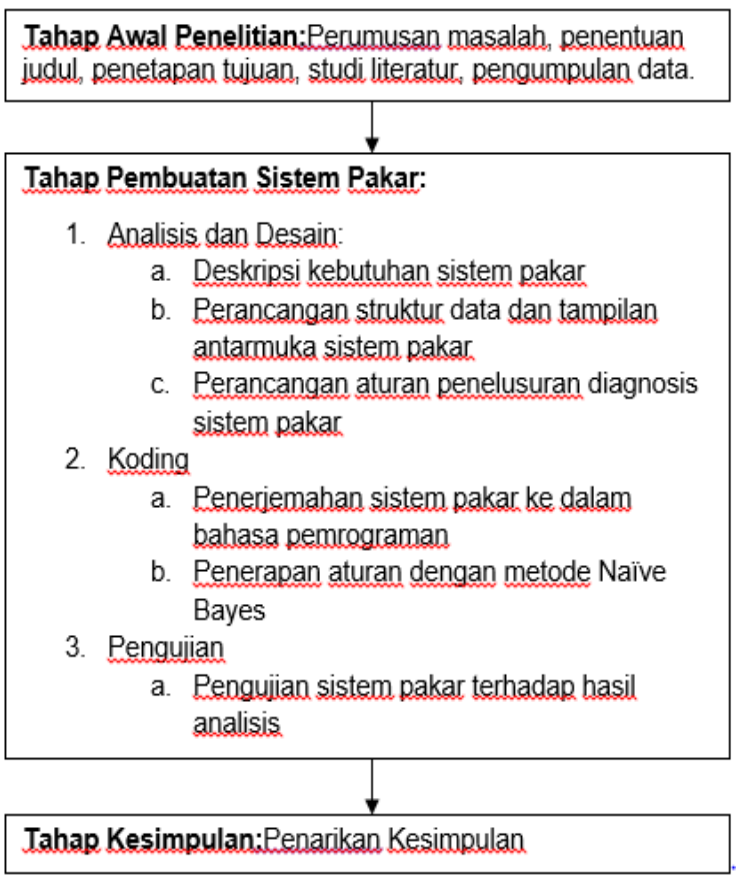

Gambar 1. Alur Penelitian

\section{HASIL DAN PEMBAHASAN}

4.1 Penentuan dan Pembobotan Gejala Untuk mengidentifikasi sejauhmana infeksi virus corona pada penderita, sebelumnya ditentukan dahulu pembobotan dari gejala yang akan digunakan sebagai indikator. Gejala-gejala tersebut dipilih sesuai dengan gejala yang dialami. Penentuan gejala terlihat pada Tabel 1.

\section{Tabel 1. Daftar Gejala}

\begin{tabular}{|l|l|}
\hline $\begin{array}{l}\text { ID } \\
\text { GEJALA }\end{array}$ & GEJALA \\
\hline G001 & $\begin{array}{l}\text { Demam }{ }^{*} \text { atau merasa panas } \\
\text { menggigil }\end{array}$ \\
\hline G002 & Batuk berdahak \\
\hline G003 & Sakit tenggorokan \\
\hline G004 & Pilek atau hidung tersumbat \\
\hline G005 & Nyeri otot atau tubuh \\
\hline G006 & Sakit kepala \\
\hline G007 & Kelelahan (mailase) \\
\hline G008 & $\begin{array}{l}\text { Dalam 14 hari pernah melakukan } \\
\text { perjalanan ke daerah negara } \\
\text { terjangkit atau daerah dengan } \\
\text { transmisi lokal? }\end{array}$ \\
\hline Galam 14 hari terakhir apakah \\
pernah kontak dengan kasus \\
konfirmasi atau probable coVID \\
19?
\end{tabular}




\begin{tabular}{|l|l|}
\hline $\begin{array}{l}\text { ID } \\
\text { GEJALA }\end{array}$ & GEJALA \\
\hline G030 & Hasil test PCR positif \\
\hline G031 & Tidak ada gejala apapun \\
\hline
\end{tabular}

Secara umum, terdapat tujuh kategori kasus infeksi virus corona, yaitu kasus terkonfirmasi, kasus probable, kasus berat, kasus sedang, kasus ringan, kasus tanpa gejala, dan kasus kontak erat. Klasifikasi infeksi virus corona diberikan oleh pakar penyakit dalam seperti pada Tabel 2 .

Tabel 2. Daftar Klasifikasi Penyakit

\begin{tabular}{|l|l|}
\hline ID PENYAKIT & PENYAKIT \\
\hline G01 & Kasus Terkonfirmasi \\
\hline G02 & Kasus Probable \\
\hline G03 & Suspek Kategori Berat \\
\hline G04 & Suspek Kategori Sedang \\
\hline G05 & Suspek Kategori Ringan \\
\hline G06 & Tanpa Gejala \\
\hline
\end{tabular}

Adapun berbagai upaya penanggulangan wabah corona dengan beberapa tindak penanggulangan berdasarkan klasifikasi infeksi virus corona. Solusi infeksi corona berdasarkan kategorinya diberikan oleh pakar penyakit dalam seperti pada Tabel 3.

Tabel 3. Daftar Solusi

\begin{tabular}{|l|l|}
\hline $\begin{array}{l}\text { ID } \\
\text { SOLUSI }\end{array}$ & SOLUSI \\
\hline S001 & $\begin{array}{l}\text { Istirahat yang cukup, minum air putih } \\
\text { yg banyak dan konsumsi obat } \\
\text { penurun panas }\end{array}$ \\
\hline & $\begin{array}{l}\text { Minum banyak air putih dan istirahat } \\
\text { cukup. Bila perlu minum antibiotik } \\
\text { atau obat batuk yang mengandung } \\
\text { ekspektoran seperti bromhexine HCI } \\
\text { danguaifenesin }\end{array}$ \\
S002 & $\begin{array}{l}\text { Minum obat pereda sakit atau } \\
\text { antibiotik, hindari kontak dengan } \\
\text { orang yang sakit dan rajin cuci } \\
\text { tangan }\end{array}$ \\
\hline S003 & $\begin{array}{l}\text { Gunakan pelembap atau penguap } \\
\text { hidung, Tempelkan handuk basah } \\
\text { dan hangat pada wajah, Minum air } \\
\text { yang cukup dan konsumsi obat yang } \\
\text { mengandung dekongesten }\end{array}$ \\
\hline S004 & $\begin{array}{l}\text { Istirahat yang cukup dan minum obat } \\
\text { pereda nyeri / paracetamol, hindari } \\
\text { angkat beban yang berat dan } \\
\text { lakukan peregangan bagian tubuh } \\
\text { yang nyeri }\end{array}$ \\
\hline S005 & $\begin{array}{l}\text { Istirahat yang cukup dan minum obat } \\
\text { S006 }\end{array}$ \\
\hline
\end{tabular}

\begin{tabular}{|c|c|}
\hline $\begin{array}{l}\text { ID } \\
\text { SOLUSI }\end{array}$ & SOLUSI \\
\hline & pereda sakit kepala / paracetamol \\
\hline S007 & $\begin{array}{l}\text { Istirahat yang cukup, konsumsi } \\
\text { vitamin C dan perbanyak makanan } \\
\text { bergizi }\end{array}$ \\
\hline S008 & $\begin{array}{l}\text { Saat tiba di rumah setelah } \\
\text { bepergian, segera mandi dan } \\
\text { berganti pakaian sebelum kontak } \\
\text { dengan anggota keluarga di rumah }\end{array}$ \\
\hline S009 & $\begin{array}{l}\text { Gunakan Masker, Cuci tangan } \\
\text { pakai } \\
\text { dan air mengalir selama } 40-60 \text { detik } \\
\text { atau menggunakan cairan antiseptik } \\
\text { berbasis alkohol (handsanitizer) } \\
\text { minimal } 20-30 \text { detik. Hindari } \\
\text { menyentuh mata, hidung dan mulut } \\
\text { dengan tangan yang tidak bersih }\end{array}$ \\
\hline S010 & $\begin{array}{l}\text { Menjaga jarak minimal } 1 \text { meter } \\
\text { dengan orang lain untuk } \\
\text { menghindari terkena droplet dari } \\
\text { orang yang yang batuk atau bersin }\end{array}$ \\
\hline S011 & $\begin{array}{l}\text { Membatasi diri terhadap interaksi } \\
\text { kontak dengan orang lain yang tidak } \\
\text { diketahui status kesehatannya }\end{array}$ \\
\hline S012 & $\begin{array}{l}\text { Meningkatkan daya tahan tubuh } \\
\text { dengan menerapkan pola hidup } \\
\text { bersih dan sehat (PHBS) seperti } \\
\text { konsumsi gizi seimbang, aktivitas } \\
\text { fisik minimal } 30 \text { menit sehari, } \\
\text { istirahat yang cukup termasuk } \\
\text { pemanfaatan kesehatan tradisional. }\end{array}$ \\
\hline & $\begin{array}{l}\text { Konsumsi Vitamin C (untuk } 14 \text { hari), } \\
\text { dengan pilihan Tablet Vitamin C non } \\
\text { acidic } 500 \mathrm{mg} / 6-8 \text { jam oral (untuk } 14 \\
\text { hari) atau Tablet isap vitamin C } 500 \\
\mathrm{mg} / 12 \text { jam oral (selama } 30 \text { hari) }\end{array}$ \\
\hline S014 & $\begin{array}{l}\text { Apabila sakit menerapkan etika } \\
\text { batuk dan bersin. Jika berlanjut } \\
\text { segera berkonsultasi } \\
\text { dokter/tenaga kesehatan }\end{array}$ \\
\hline S015 & $\begin{array}{l}\text { Istirahat yang cukup, minum air putih } \\
\text { yg banyak dan konsumsi obat } \\
\text { penurun panas }\end{array}$ \\
\hline SO & $\begin{array}{l}\text { Minum air hangat, konsumsi obat } \\
\text { pereda batuk yang mengandung } \\
\text { Antihistamin, Diphenhydramine, dan } \\
\text { amonium klorida }\end{array}$ \\
\hline S017 & $\begin{array}{l}\text { Istirahat yang cukup, } \text { konsumsi } \\
\text { vitamin C dan perbanyak makanan } \\
\text { bergizi }\end{array}$ \\
\hline S018 & Konsultasikan ke Dokter \\
\hline So & $\begin{array}{l}\text { Gunakan pelembap atau penguap } \\
\text { hidung, Tempelkan handuk basah } \\
\text { dan hangat pada wajah, Minum air } \\
\text { yang cukup dan konsumsi obat yang } \\
\text { mengandung dekongesten }\end{array}$ \\
\hline & $\begin{array}{l}\text { Banyak istirahat, minum air putih } \\
\text { yang cukup, minum antibitoik / } \\
\text { konsultasikan ke dokter }\end{array}$ \\
\hline
\end{tabular}




\begin{tabular}{|c|c|}
\hline $\begin{array}{l}\text { ID } \\
\text { SOLUSI }\end{array}$ & SOLUSI \\
\hline S021 & $\begin{array}{l}\text { Hindari mengucek mata, segera cuci } \\
\text { tangan apabila tidak sengaja } \\
\text { menyentuh mata, jika terasa kotor } \\
\text { bersihkan dengan kapas yang } \\
\text { dibasahi air bersih dan hindari } \\
\text { menggunakan lensa kontak. }\end{array}$ \\
\hline S022 & $\begin{array}{l}\text { Minum obat pereda sakit atau } \\
\text { antibiotik, hindari kontak dengan } \\
\text { orang yang sakit dan rajin cuci } \\
\text { tangan }\end{array}$ \\
\hline S023 & $\begin{array}{l}\text { Istirahat dan atur pernapasan, } \\
\text { Konsultasikan ke dokter }\end{array}$ \\
\hline S024 & $\begin{array}{l}\text { Istirahat total, intake kalori adekuat, } \\
\text { kontrol elektrolit, status hidrasi } \\
\text { (terapi cairan), dan oksigen }\end{array}$ \\
\hline S025 & $\begin{array}{l}\text { Istirahat yang cukup, minum air putih } \\
\text { yg banyak dan konsumsi obat } \\
\text { penurun panas }\end{array}$ \\
\hline S026 & $\begin{array}{l}\text { Gunakan obat gatal dan periksakan } \\
\text { ke dokter jika ruam kulit semakin } \\
\text { parah }\end{array}$ \\
\hline S027 & $\begin{array}{l}\text { Oleskan minyak kayu putih pada } \\
\text { perut, minum air hangat }\end{array}$ \\
\hline S028 & Konsultasikan ke dokter/psikolog \\
\hline S029 & $\begin{array}{l}\text { Konsumsi obat sesuai dengan } \\
\text { penyebab nyeri, apakah karena } \\
\text { masalah jantung, paru-paru, } \\
\text { kolesterol atau batuk }\end{array}$ \\
\hline S030 & $\begin{array}{l}\text { Pikiran positif: menjauhkan dari } \\
\text { informasi hoax, mengenang semua } \\
\text { pengalaman yang menyenangkan, } \\
\text { bicara pada diri sendiri tentang hal } \\
\text { yang positif (positive self-talk), } \\
\text { responsif (mencari solusi) terhadap } \\
\text { kejadian, dan selalu yakin bahwa } \\
\text { pandemi akan segera teratasi, jika } \\
\text { perlu hubungi psikolog }\end{array}$ \\
\hline S031 & Isolasi Mandiri 14 hari \\
\hline S032 & $\begin{array}{l}\text { Isolasi Mandiri } 14 \text { hari dan kontrol ke } \\
\text { FKTP }\end{array}$ \\
\hline S033 & $\begin{array}{l}\text { Isolasi } 14 \text { hari di rumah sakit darurat } \\
\text { covid }\end{array}$ \\
\hline S034 & $\begin{array}{l}\text { Isolasi } 14 \text { hari di rumah sakit rujukan } \\
\text { covid }\end{array}$ \\
\hline $\mathrm{S} 03$ & $\begin{array}{l}\text { Menerapkan adaptasi kebiasaan } \\
\text { baru dengan melaksanakan protokol } \\
\text { kesehatan dalam setiap aktivitas }\end{array}$ \\
\hline
\end{tabular}

\subsection{Interface Pengguna}

Sistem pakar dalam penelitian ini adalah sistem pakar berbasis web. Untuk dapat melakukan proses diagnostik, pengguna harus masuk terlebih dahulu. Jika pengguna tidak memiliki nama login dan kata sandi, pengguna dapat memilih menu login. Tampilan awal web sistem pakar diagnosa covid-19 dapat dilihat pada Gambar 2.

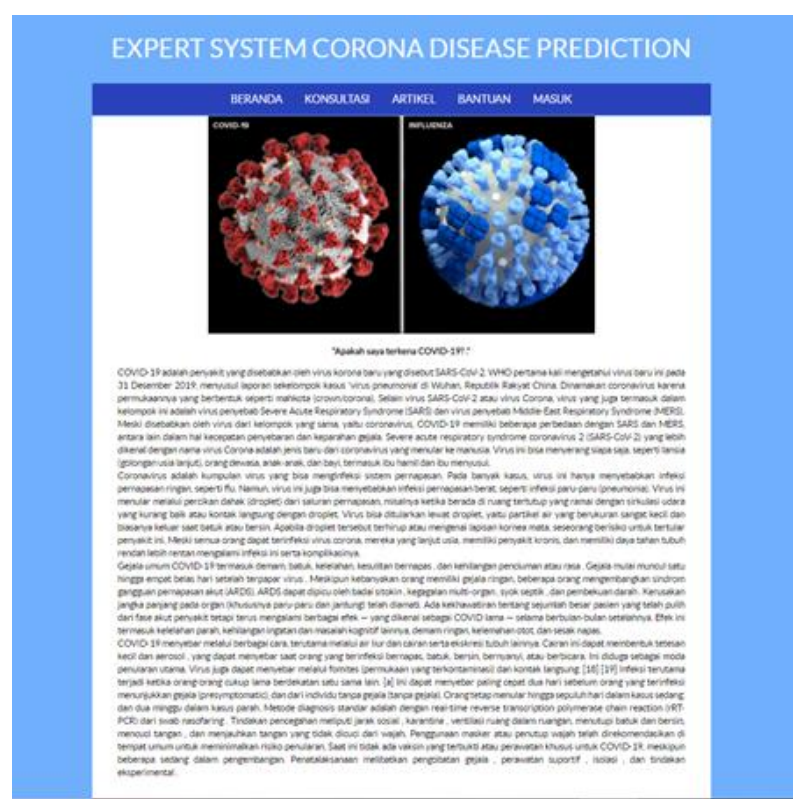

\section{Gambar 2. Interface Web Sistem Pakar}

Setelah pengguna berhasil login, pengguna dapat memulai proses konsultasi. Konsultasi dilakukan dalam tiga tahap: memilih gejala, meninjau gejala, dan mendapatkan hasil konsultasi. Untuk memilih gejala, pengguna harus memberikan daftar gejala yang dialami. Halaman konsultasi dapat dilihat pada Gambar 3.

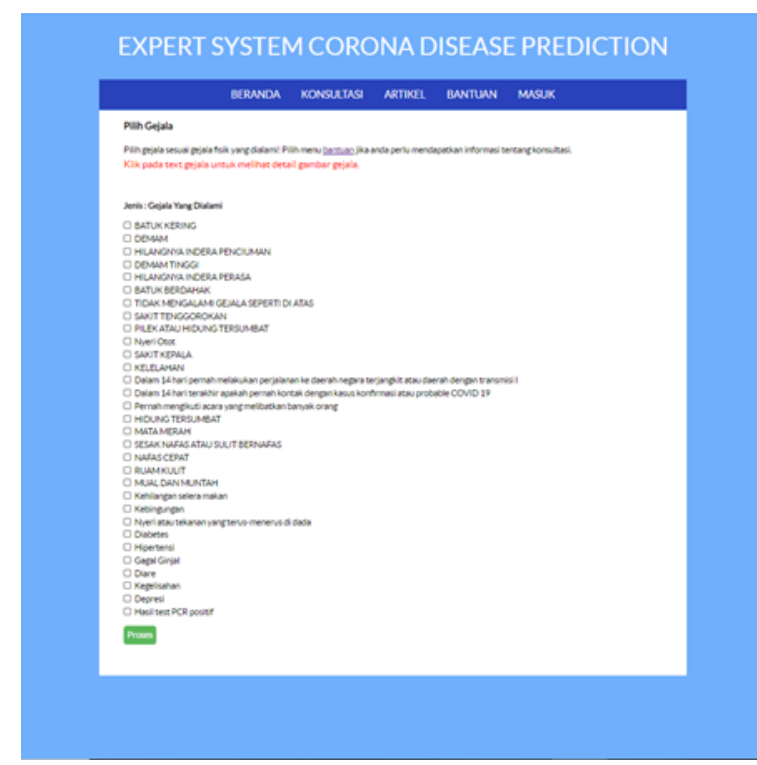

Gambar 3. Halaman Konsultasi

Setelah pengguna menentukan jawaban yang dipilih, pengguna dapat melanjutkan proses untuk mendapatkan hasil konsultasi. Hasil konsultasi akan menunjukkan sejauh mana virus menginfeksi tubuh manusia dan solusinya. Halaman hasil identifikasi dapat dilihat pada Gambar 4. 


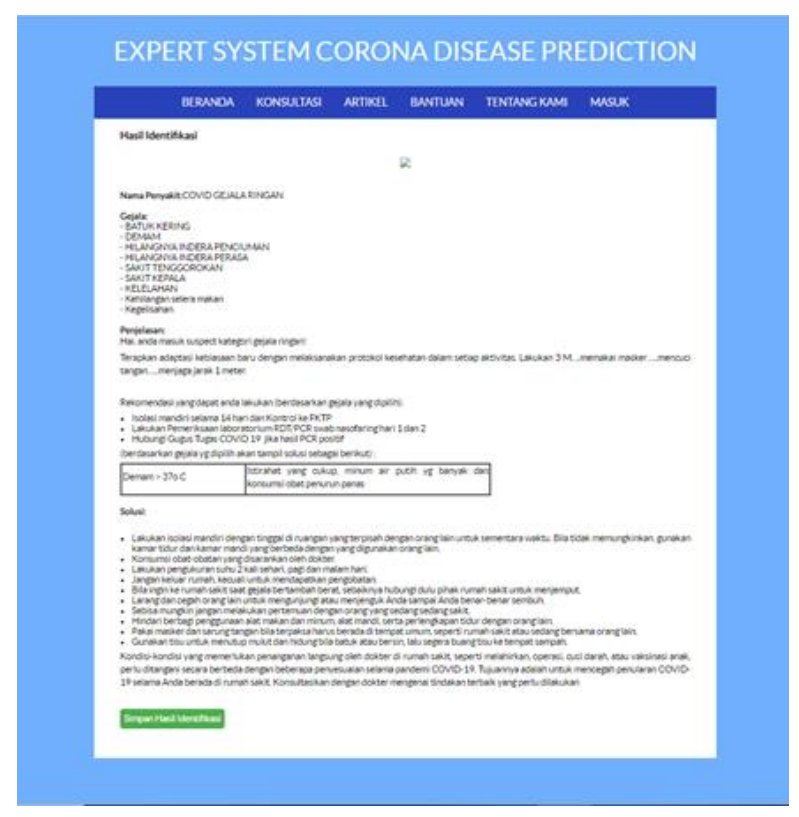

Gambar 4. Hasil Identifikasi

\subsection{Implementasi Perhitungan}

Berikut merupakan contoh implementasi penghitungan untuk mendapatkan hasil diagnose virus corona. Persamaan yang digunakan pada penghitungan ini adalah persamaan (1). Pada Gambar 5 sistem menampilkan keseluruhan gejala yang mungkin dialami pengguna. Pengguna dihadapkan pada selection box daftar gejala. Berdasarkan Gambar 5 pengguna memilih 6 gejala yang dialami.

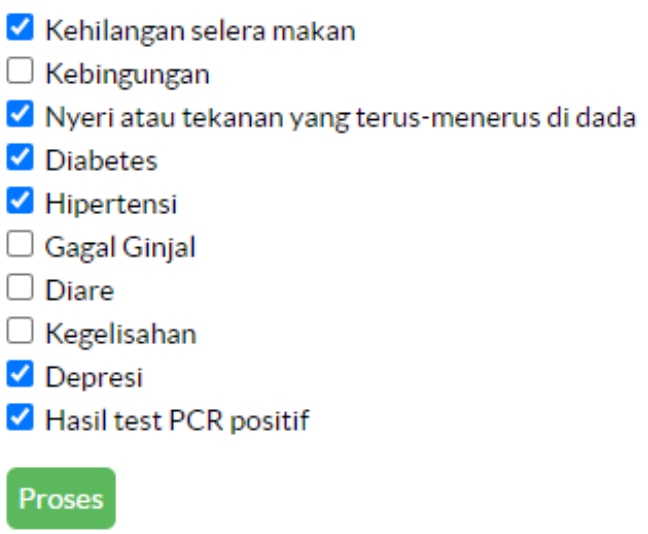

\section{Gambar 5. Pemilihan Gejala}

Berdasarkan Gambar 6 diperoleh kesimpulan berdasarkan gejala yang dialami pengguna sebelumnya berikut dengan solusi yang dapat dilakukan sebagai langkah awal penanganan sebelum selanjutnya mendapatkan tindakan medis yang tepat.

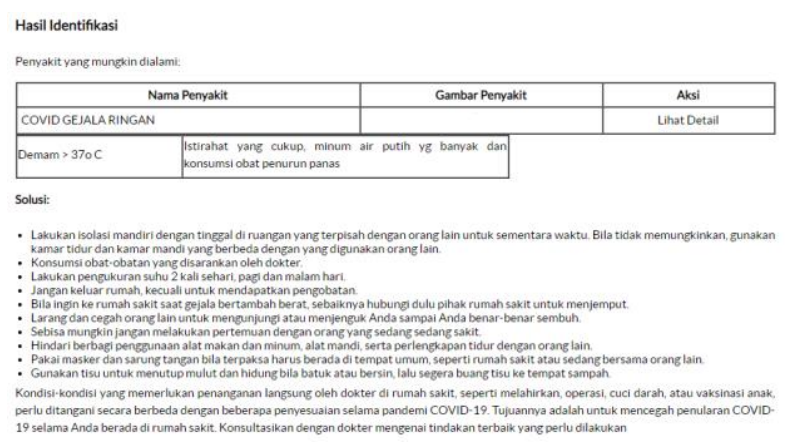

\section{Gambar 6. Hasil Konsultasi}

\subsection{Pengujian dan Responden}

Pengujian yang dilakukan oleh sistem pakar diagnosis virus corona dilakukan dengan metode black box. Lakukan penghitungan manual dan bandingkan hasilnya dengan hasil konsultasi sistem. Hasil pengujian menunjukkan bahwa hasil perhitungan manual sama dengan hasil konsultasi sistem.

Setelah dilakukan uji black box, berdasarkan Gambar 7, dilakukan uji sistem pakar diagnosa virus corona pada beberapa narasumber. Narasumber terdiri dari 17 orang, berusia antara 15-55 tahun, dan melakukan rapid test di berbagai tempat. Gambar 5 menunjukkan bahwa, $47 \%$ responden mengalami gejala ringan, $18 \%$ mengalami gejala sedang, $17 \%$ mengalami gejala berat, $6 \%$ probable, $6 \%$ terkonfirmasi mengidap covid-19, dan $6 \%$ tanpa gejala.

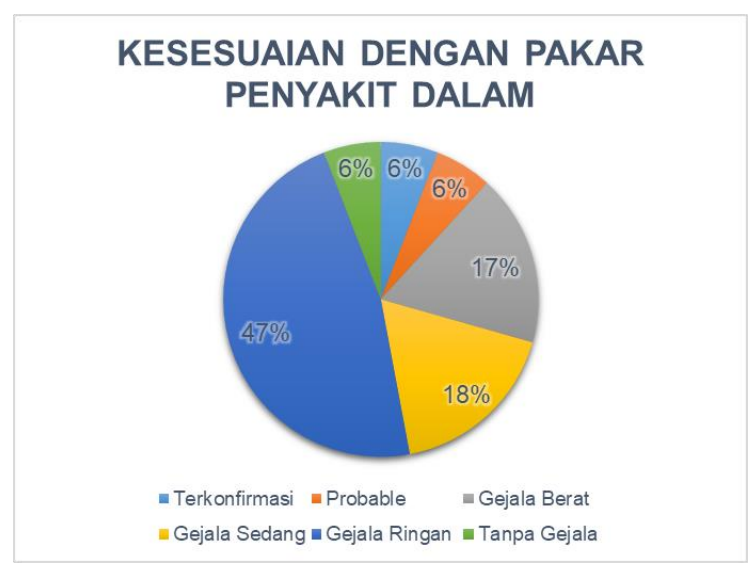

\section{Gambar 7. Diagram Klasifikasi Infeksi Virus Corona}

Gambar 8 menunjukkan bahwa dari 17 data uji tersebut dilakukan pengujian validasi dengan cara membandingkan keluaran sistem dengan pendapat pakar. Dari 17 data uji terdapat 1 data uji yang tidak cocok. Sehingga didapatkan tingkat kesesuaian sistem pakar ini sebesar $94,12 \%$ dan $5,88 \%$ hasil konsultasi sistem pakar tidak sesuai dengan 
hasil konsultasi dokter dan tenaga kesehatan masing-masing responden.

\section{KESESUAIAN DENGAN PAKAR PENYAKIT DALAM}

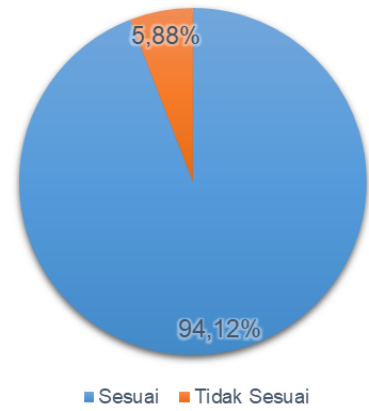

\section{Gambar 8. Diagram Kesesuaian Sistem Pakar}

Gambar 9 menunjukkan bahwa untuk kasus yang dikonfirmasi, hasil sistem pakar dan hasil pakar adalah 1. Untuk kasus yang memungkinkan, hasil dari sistem pakar dan hasil pakar adalah 1. Untuk kasus yang parah, hasil ahli adalah 1. Hasil sistem dan pakar adalah 3. Untuk kasus dengan gejala sedang, hasil sistem pakar adalah 3 dan hasil pakar adalah 4. Untuk gejala yang lebih ringan diperoleh hasil sistem pakar 8 dan hasil pakar 7. Untuk kasus asimtomatik, hasil sistem pakar dan hasil pakar adalah 1.

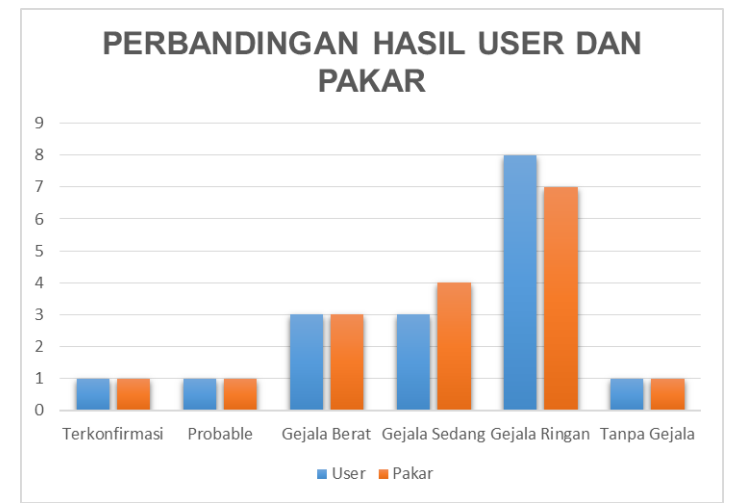

Gambar 9. Grafik Perbandingan Hasil

\section{PENUTUP}

Berdasarkan pembahasan di atas, dapat disimpulkan bahwa sistem pakar diagnosa virus corona memenuhi persyaratan ahli obat internal dengan tingkat kualifikasi 94\%. Sehingga, sistem pakar ini dapat membantu user untuk mengetahui sejauhmana virus corona menginfeksi tubuh supaya dapat diketahui langkah apa yang sebaiknya dilakukan. Namun, penelitian ini masih memiliki banyak kekurangan, antara lain pengujian hanya menggunakan metode blackbox. Oleh sebab itu, pengembangan pada penelitian berikutnya sangat diharapkan. Pengembangan yang diharapkan pada penelitian berikutnya adalah pengujian whitebox dan greybox, serta konfirmasi yang lebih lanjut dan intens dengan dokter penyakit dalam terkait sistem pakar.

\section{DAFTAR PUSTAKA}

[1] V. No and N. Mona, "Konsep Isolasi Dalam Jaringan Sosial Untuk Meminimalisasi Efek Contagious (Kasus Penyebaran Virus Corona Di Indonesia)," J. Sos. Hum. Terap., vol. 2, no. 2, pp. 117-125, 2020.

[2] J. Singla, D. Grover, and A. Bhandari, "Medical Expert Systems for Diagnosis of Various Diseases," Int. J. Comput. Appl., vol. 93, no. 7, pp. 36-43, 2014.

[3] L. R. Fleaih, "Expert system for Diagnosing Kidney diseases," Int. J. Comput. Technol., vol. 14, no. 3, pp. 5517-5528, 2015.

[4] A. Hananti, "Ketahui Perbedaan COVID-19 dengan SARS dan MERS," 2020. [Online]. Available: https://www.alodokter.com/ketahuiperbedaan-covid-19-dengan-sars-danmers.

[5] M. D. C. Pane, "SARS," 2020. [Online]. Available: https://www.alodokter.com/sars.

[6] J. S. M. Peiris et al., "Coronavirus as a possible cause of severe acute respiratory syndrome," Lancet, vol. 361, no. 9366, pp. 1319-1325, 2003.

[7] Admin, "Middle East Respiratory Syndrome (MERS)." [Online]. Available: https://covid19.kemkes.go.id/penyakitvirus/middle-east-respiratory-

syndrome-mers/. [Accessed: 07-Jul1BC].

[8] A. Zumla, D. S. Hui, and S. Perlman, "Middle East respiratory syndrome," Lancet, vol. 386, no. 9997, pp. 9951007, 2015.

[9] M. F. A. Saputra, T. Widiyaningtyas, and A. P. Wibawa, "Illiteracy Classification Using $\mathrm{K}$ Means-Naïve Bayes Algorithm," JOIV Int. J. Informatics Vis., vol. 2, no. 3, p. 153, 2018.

[10] R. Anusha and A. Prof, "Predicting the Student's Preference Between 
Conventional Learning and ELearning," vol. 29, no. 4, pp. 59175922, 2020.

[11] U. Erkan and L. Gökrem, "the Classification of the Students Success Via the Informations Existing in ESchool System," Int. J. Educ. Res., vol. 4, no. 4, pp. 225-232, 2016. 